\title{
DETERMINANTS OF ADOLESCENT MARRIAGES INHIBITING THE MATURING OF MARRIAGE AGE
}

\author{
Norma Yuni Kartika ${ }^{1}$ Muhammad Efendi ${ }^{2}$ Ellyn Normelani ${ }^{3}$ Nurhidayah $^{4}$ \\ ${ }^{1234}$ Geography Department, Faculty of Social Science and Political Science, \\ Lambung Mangkurat University \\ E-mail: norma.kartika@ulm.ac.id
}

\begin{abstract}
Incidence of adolescent marriages in South Kalimantan is still high and acts an obstacle to maturing the marriage age program. This paper aims to analyze the dominant factors which contribute to the maturity of women's marriages by modifying the social ecological framework theory. This survey study had 180 respondents with 113 women who were married under 19 years and 47 respondents who were married at 19-30 years, while the anlaysis was using bivariate and multivariate analysis. The variables used refer to the social ecological framework theory and there are 2 variables used here, namely individuals (education and work status) and interpersonal (father's education, father's occupation and the economy of the respondent's previous household). The results of the bivariate analysis are in line with social ecological framework theory. Furthermore, the results of multivariate analysis show that all of these variables are 35.7 percent influencing the adolescent marriages. Based on multivariate analysis, the most influential determinants on adolescent marriages are respondents from poor households before marriage, father's working in agriculture, respondents do not work, fathers do not graduate from elementary school and respondents have low education.
\end{abstract}

Keywords: Determinants, Marriages, Adolescents, Maturing

\section{A. INTRODUCTION}

Amendment of Marriage Law No. 1/1974 to (Undang-Undang Republik Indonesia Nomor 16 Tahun 2019 Tentang Perkawinan, 2019) which was ratified in October 2019 contained several revised points which was including the minimum age limit for a person to be permitted to marry. The previous law before being amended states that for women to be permitted to marry, they must be at least 16 years and for men, it is 19 years. Meanwhile in the new marriage law, there is no gender bias in the minimum age limit for marriage between men and women which is 19 years.

The changes in the marriage law is due to the phenomenon in Indonesia which shows that there are still many women who marry at younger age or at the age of children. The essential issue regarding the age of first marriage is the high incidence of early marriage and the impact which must be borne by so many subjects of child marriages to be considered. One of the studies in Indonesia which conducted 
by (National Population and Family Planning Board (BKKBN), Statistics Indonesia (BPS), Ministry of Health (Kemenkes), 2018) found that 1 in 9 girls were married at child age. Women aged 20-24 years who are married before the age of 18 in 2018 are estimated to reach $1,220,900$ and this figure puts Indonesia among the 10 countries with the highest absolute child marriage rates in the world (BPS, 2020).

Teenagers or adolescents from the Latin word: adolecere (a Dutch word, adolesencia which means adolescent) which means to grow or grow to be adulthood (Hurlock, 1999). The term adolescent has a broad meaning in mental, emotional, spatial and physical maturity. Adolescence is a transition from childhood to adulthood, which starts as a child and ends when one is an adult. Adolescents also defined as a period of development or the transition from childhood to adulthood, which is followed by biological, cognitive and socio-emotional development (Santrock, 2003). The age limit for adolescents according to $\mathrm{WHO}$ is 15 to 24 years. Meanwhile according to the Ministry of Health of Republic of Indonesia, the age limit is 10 to 19 years and not yet married. According to $\mathrm{BKKBN}$, someone is defined as an adolescent if one is from 10 to 19 years (Wahyuni et al., 2009). In this paper the early marriage is the age of first marriage of girls under 19 years. This age limit is referring to the marriage law No. 16/2019 and the definitian of adolescents according to experts.

Marriage is not a simple task, especially for girls who are still under the category of adolesncents. In order to establish a strong and harmonious family, mental and physical readiness are required by both of the bride and groom. A strong and harmonious family are the basic of quality community life. Child marriages have many risks, especially for the young women. In the age of teenagers, girls should be having their time to get education, have fun, preserve the reproductive health, health, freedom of expression and free of discrimination. When they are forced to get into marriage, those primarily moments will be vanished.

The rate of early marriages in many countries continues to increase annually and is always associated with various efforts to protect the law against children (Muntamah et al., 2019). In Indonesia every year there are 1.5 million girls who get married early and the figure is equivalent to one teenager to get married every two 
seconds (Chae \& Ngo, 2017). Early marriage is not a new phenomenon in Indonesia. The causes and impacts are varied by province in Indonesia. This theme is oftenly discussed in various discussions, seminars and researchers. In fact, it has became a target of achievement for human development in various countries including Indonesia. The theme of early marriage is an interesting issue to be discussed and studied thoroughly from various fields of science, on both the causes and effects of early marriages.

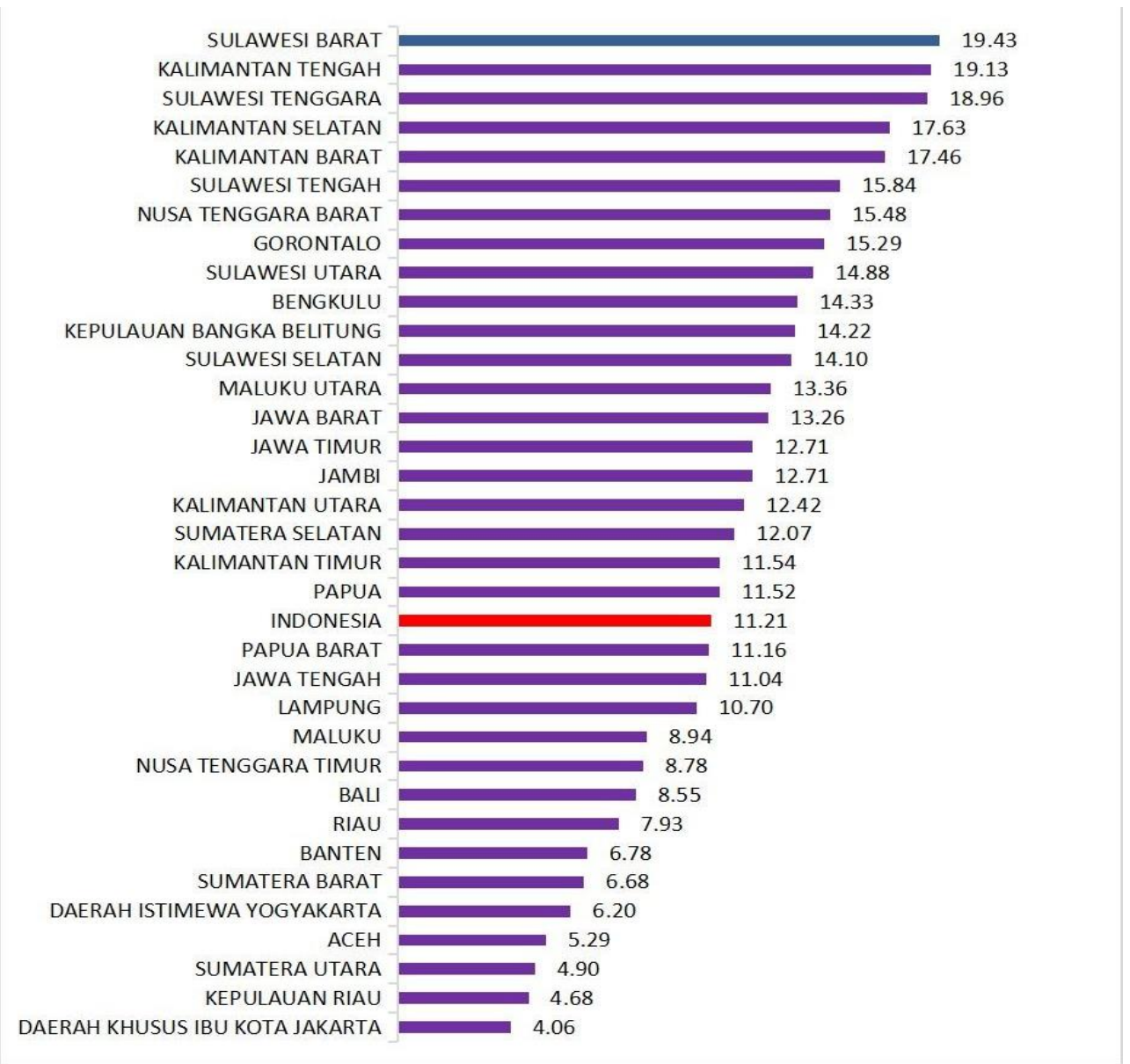

Figure 1 Percentage of Women Age 20-24 whose Age of the First Marriage is Under 18 Years based on Province in Indonesia (BPS and the Ministry of National Development Planning/Bappenas, 2020)

Based on province in Indonesia in 2018 (Figure 1), South Kalimantan Province is on the fourth rank with 17.63 percent of women aged $20-24$ years whose first marriage age is under 18 years, which is far above the national percentage at 11.21 percent. In relation to the high number of child age 
marriages which occur in South

Kalimantan, this has hampered the achievement of the 5th Sustainable Development Goals (SDGs) on achieving gender equality and empowering all women and girls. To precisely, this fact hampered the target of SDGs 5.3 in elimination of all harmful practices such as child marriage which must be achieved until 2030. Marriage Age Maturing Program (Pendewasaan Usia Perkawinan/PUP) is one of the programs on efforts to increase the age at first marriage and it is expected that women to be married at least at the age of 21 years and men at the minimum of 25 years.

This paper is based on a survey research and aims to recognize the dominant factors which contribute to the maturity of women's marriage age in terms of the level of education, work status, economic level of the household from the respondent, father's education and occupation of the respondent's father at the provincial level, namely in South Kalimantan Province. According to the social ecological framework theory, individual behavior are effected by multiple factors (Mcleroy et al., 1988). Within the theoretical framework, there are five levels, namely the individual level, the interpersonal level, the community, the institutional level, and the societal level, while there are two levels used in this study with the exceptional of community, institutional and societal. The conceptual framework is as shown in Figure 2.

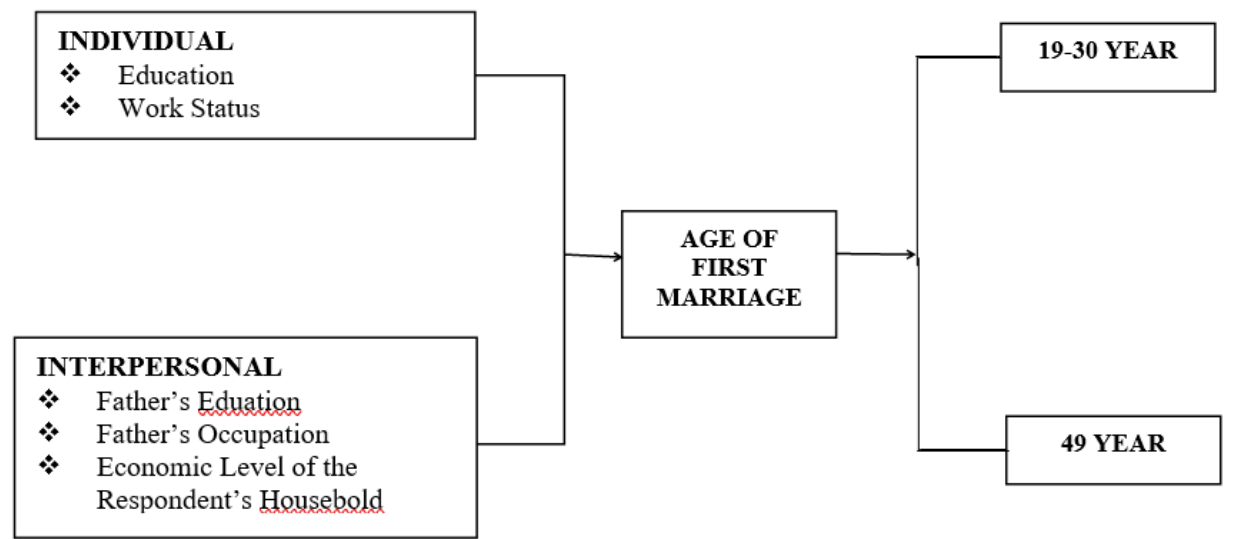

Figure 2. Conceptual Framework of the Research 


\section{B. MATERIALS AND METHODS}

The research location was in Raya Belanti Village, Binuang District, Tapin Regency, South Kalimantan Province. The selection of research locations was conducted purposively based on the highest child marriage cases at each level of the administrative area of government. The village level was chosen due to 95 percent of the women population were allowed to marry under the minimum age by law No. 16/2019 concerning marriages in Indonesia or in other words, they were married under the age of 19 years.

Survey data analysis is designed by using a quantitative approach. The analysis population was 113 women respondents who married under 19 years and 47 women respondents who married 19-30 years. The leastwise number of women respondents married over 19 years is due to the high incidence of child marriages in the area. Another criterion is the marriage of women who are legally and religiously married. Determination of the age range of 19 years refers to the minimum age limit permitted to marry according to the revised marriage law, while the 30 year limit considers the reproductive health side according to suggestion from BKKBN (National Family Planning Coordinating Agency) which states that the best reproductive range of women to get pregnant and give birth is $20-30$ years. According to BKKBN and WHO, those under the age of 19 are categorized as teenagers. So in this study adolescent marriages refer to Marriage Law No. 16/2019 as for the definition of adolescents, it is according to BKKBN and WHO.

In addition to the research, descriptive statistical analysis is through stages, namely bivariate and multivariate. Bivariate analysis analyzes the relationship between independent and dependent variable. Meanwhile multivariate analysis is to determine which variable is the most dominant contributing to the maturity of marital age using logistic regression. Stages in logistic regression modeling include determining significant variables in bivariate analysis using the chi square test of the independent variables which are linked to the dependent variable. If the value of $\mathrm{p}<0.005$ then the variable enters the multivariate analysis stage. Furthermore, the independent variables are analyzed using logistic regression simultaneously from the significant variables in the chi square test. All variables at this stage contain two categories or dummy variables. 
C. RESULTS AND DISCUSSION

Relation Between Factors of Individual, Interpersonal, Societal and Adolescent Marriages

Result of the analysis of the relationship of independent variables (individual and interpersonal) and dependent shows that all of these variables have a significant relationship to the adolescent marriage. Meanwhile the education variables of the respondents were divided into two, namely low (not going to school, not graduating from elementary school and graduating from elementary school) and high (graduating from junior high, high school and university). It is slightly different from the father's education variables, the education of respondents was divided into low (not going to school and not completing elementary school) and high (graduating elementary school, junior high, high school and university).

The variable of work status is divided into not working and working. According to (BPS, 2020), working was an economic activity carried out by someone with the intention of earning income or profit, at least 1 hour (uninterrupted) in the past week. These activities also included the activities of unpaid workers who assisted in a business/economic activity. Household economic variables are divided into poor and not poor. As for the father's work, it is divided into two, namely working in agriculture and non-agriculture. 
Table 1. Test Result of Chi Square on Variables Effecting the Adolescent Marriages

\begin{tabular}{|c|c|c|c|c|c|c|c|c|c|}
\hline \multirow[t]{3}{*}{ No } & \multirow[t]{3}{*}{ Variables } & \multicolumn{4}{|c|}{ Age of the First Marriage } & \multirow{3}{*}{$\begin{array}{r}\text { Value } X^{2} \\
\text { Calculated }\end{array}$} & \multirow[t]{3}{*}{ Df } & \multirow{3}{*}{$\begin{array}{l}\text { Value } \\
X^{2} \\
\text { Table }\end{array}$} & \multirow{3}{*}{$\begin{array}{l}\text { Value } \\
\text { of Sig. }\end{array}$} \\
\hline & & \multicolumn{2}{|c|}{$\begin{array}{l}\text { Adolescent } \\
\text { Marriage } \\
(<19)\end{array}$} & \multicolumn{2}{|c|}{$\begin{array}{l}\text { Non- } \\
\text { Adolescent } \\
\text { Marriage } \\
(19-30)\end{array}$} & & & & \\
\hline & & $\mathrm{n}$ & $\%$ & $\mathrm{n}$ & $\%$ & & & & \\
\hline 1. & $\begin{array}{l}\text { Education } \\
\text { Low High }\end{array}$ & $\begin{array}{l}83 \\
30 \\
\end{array}$ & $\begin{array}{l}73.5 \\
26.5\end{array}$ & $\begin{array}{l}20 \\
27 \\
\end{array}$ & $\begin{array}{l}42.6 \\
57.4\end{array}$ & $13.818 *$ & 1 & 3.84 & $0.000 *$ \\
\hline 2. & $\begin{array}{l}\text { Work Status Working } \\
\text { Not Working }\end{array}$ & $\begin{array}{l}43 \\
70\end{array}$ & $\begin{array}{l}38.1 \\
61.9\end{array}$ & $\begin{array}{r}8 \\
39 \\
\end{array}$ & $\begin{array}{l}17 \\
83\end{array}$ & $6.762 *$ & 1 & 3.84 & $0.009 *$ \\
\hline 3. & $\begin{array}{l}\text { Economic Level of } \\
\text { the } \\
\text { Household } \\
\text { Poor } \\
\text { Not poor }\end{array}$ & $\begin{array}{r}102 \\
11\end{array}$ & $\begin{array}{c}90.3 \\
9.7\end{array}$ & $\begin{array}{l}27 \\
20\end{array}$ & $\begin{array}{l}57.4 \\
42.6\end{array}$ & $22.887^{*}$ & 1 & 3.84 & $0.000 *$ \\
\hline 4. & $\begin{array}{l}\text { Father's Eduation } \\
\text { Low } \\
\text { High }\end{array}$ & $\begin{array}{l}58 \\
55 \\
\end{array}$ & $\begin{array}{l}51.3 \\
49.7 \\
\end{array}$ & $\begin{array}{l}14 \\
33 \\
\end{array}$ & $\begin{array}{l}29.8 \\
70.2 \\
\end{array}$ & $4.827 *$ & 1 & 3.84 & $0.028 *$ \\
\hline 5. & $\begin{array}{l}\text { Father's Occupation } \\
\text { Agriculture } \\
\text { Non-agriculture }\end{array}$ & $\begin{array}{l}74 \\
39\end{array}$ & $\begin{array}{l}65.5 \\
34.5\end{array}$ & $\begin{array}{l}19 \\
28\end{array}$ & $\begin{array}{l}40.4 \\
59.6\end{array}$ & $8.565^{*}$ & 1 & 3.84 & $0.003 *$ \\
\hline
\end{tabular}

Source: Primary Data, 2020

Based on Table 1, the majority of married women in adolescents age is having low or no education/do not complete elementary school/complete elementary school. The percentage could reach to 73.5 percent. Meanwhile only 26.5 percent of them have high education or have completed junior high school or above. In contrast, the unmarried women in adolescents age are highly educated which is proved by the percentage of 57.4 percent, while 42.6 percent have low education. That means that women who engage in adolescent marriages are higher in those with low education, conversely those who do not engage in adolescent marriages are those with higher education. Women's education has a significant relationship with adolescent marriages which shows with $p$ value $<0.005$. Findings from Susenas (National Socio-Economic Household Survey The National Socioeconomic Survey) and literature studies show that children who are more vulnerable to child marriages are girls, children who live in poor families, in rural areas and have low education (BPS\&UNICEF, 2016; BPS, 2020; Nasution, 2016).

The number of married women in their teens was 61.9 percent and 38.1 percent were unemployed. On the contrary, most of those who were 
married not in their teens worked (83 percent) and only 17 percent of them who did not work. There are more women who engage in teenage marriages come from those who do not work. This condition is indicated by the existence of a significant relationship between work status and adolescent marriage at $\mathrm{p}<0.005$. Female workers aged 18 and under are more likely to work in the informal sector and are therefore more vulnerable when compared to women in the same age group who marry after the age 18 years and work (BPS, 2020; Pitoyo et al., 2011).

There are 90.3 percent of the adolescent marriages come from the poor families and 9.7 percent from nonpoor families. Among the unmarried girls in their teens, 57.4 percent came from poor families and 42.6 percent came from non-poor families. This means that in majority, the adolescents who come from poor family are married under the age of 19 years. More adolescent marriages originating from poor families could be seen from the meaningful relationship between the household economy of the respondent's origin and adolescent marriages at $\mathrm{p}$ $<0.005$. (Handayani, 2014) stated that young women whose parents did not work would be at risk 7.4 times to engage in an early marriage compared to young women whose parents worked. In her research, it was concluded that the factors most at risk of causing children to get married early was when their parents did not work so it was automatically an economic factor.

In the families with highly educated fathers, they tend not to marry off their teenagers daughters. This also happened in this study as shown in Table 1. There are 51.3 percent of women who were married in their teens had fathers with low education or did not attend school/did not complete elementary school. Meanwhile the remaining 49.7 percent had fathers with high education or graduated elementary school and above. The opposite pattern occurs in the unmarried women in their teens, 70.2 percent of their fathers have high education and 29.8 percent have low education. That means that in the adolescent marriages, father's education is higher in lower education, on the contrary in the non-adolescent marriages, higher percentage comes from fathers with higher education. With a $\mathrm{p}$ value $<0.005$, it indicates that the education of the respondent's father has a significant relationship with adolescent marriage.

There are 65.5 percent of the 
married women in their teens have fathers who work in agriculture and 34.5 percent in the non-agricultural fields. Furthermore, 59.6 percent women who married not in the age of teenagers worked in non-agricultural fields and 40.4 percent in the agriculture field. Father's occupation in agriculture is higher in adolescent marriages, whereas father's occupation in non-agricultural fields is higher in non-child marriages. This condition is shown by the existence of a significant relation between father's work and adolescent marriage (Table 1). Based on the level of welfare, women aged 20-24 years who come from the lowest welfare level households tend to have a greater chance of marriage at the age of under 18 years. Meanwhile, those from households with the highest welfare rates have the lowest prevalence of marriage before the age of 18 years (BPS, 2020). Seeing from the socio- economic problems, early marriages are usually followed by economic unpreparedness (Pohan, 2017).
Contribution of Individual and Interpersonal Factors to the Adolescent Marriages

Multivariate analysis in this paper is used to see the relationship between independent variables, namely household economy, respondent education, respondent's work status, father's education and father's work status with the dependent variable (adolescent marriage). The test used was logistic regression analysis with a significance level of $\mathrm{p}<0.05$ and the results of the statistical tests in this study showed a significance value of 0,000 (Table 2) which showed that it had a significant relationship.

Based on a series of stages of the multivariate analysis process presented in Table 1, the rank is introduced from the most dominant contributing to adolescent marriages. In general, the poverty of the respondent's household, the work of the respondent's father, the work of the respondent, the education of the respondent's father and the education of the respondent have caused adolescent marriage by 35.7 percent. It is indicated by the Determinant Coefficient $\left(\mathrm{R}^{2}\right)$. 
Table 2 Result of Multivariate Analysis Causing the Adolescent Marriages

\begin{tabular}{|l|c|c|}
\hline \multicolumn{1}{|c|}{ Variables } & Odde Ratio (OR) & Coefficient (B) \\
\hline $\begin{array}{l}\text { Poverty of the Respondent's } \\
\text { Previous } \\
\text { Household }\end{array}$ & 8.1 & 2.082 \\
\hline Occupation of Respondent's Father & 5.1 & 1.622 \\
\hline Occupation of Respondent & 2.9 & 1.073 \\
\hline Education of Respondent's Father & 1.6 & 0.492 \\
\hline Education of Respondent & 0.8 & -0.198 \\
\hline Value of Significance (P) & \multicolumn{2}{|c|}{$0.000^{*}$} \\
\hline Determinant Coefficient $\left(\mathrm{R}^{2}\right)$ & \multicolumn{2}{|c|}{0.357} \\
\hline
\end{tabular}

Source: Primary Data, 2020

Factors Causing the Adolescent

\section{Marriages}

This analysis refers to the social ecological framework theory which influences individual behavior related to adolescent marriages. If considered from the individual variables (poorly educated and not working) and interpersonal (coming from poor households, fathers not graduating from elementary school, and fathers working in agriculture), they have a significant relation to the adolescent marriages at p> 0,000 . The results of the bivariate analysis are in line with social ecological framework theory.
Furthermore, the results of multivariate analysis show that all of these variables 35.7 percent influenced adolescent marriages. Based on multivariate analysis, the most influential on adolescent marriages are respondents from poor households before marriage, then fathers worked in agriculture, respondents did not work, fathers did not graduate from elementary school and respondents had low education. Reconstruction of the theory of adolescent marriages is originated from the social ecological framework theory as shown in Figure 3. 


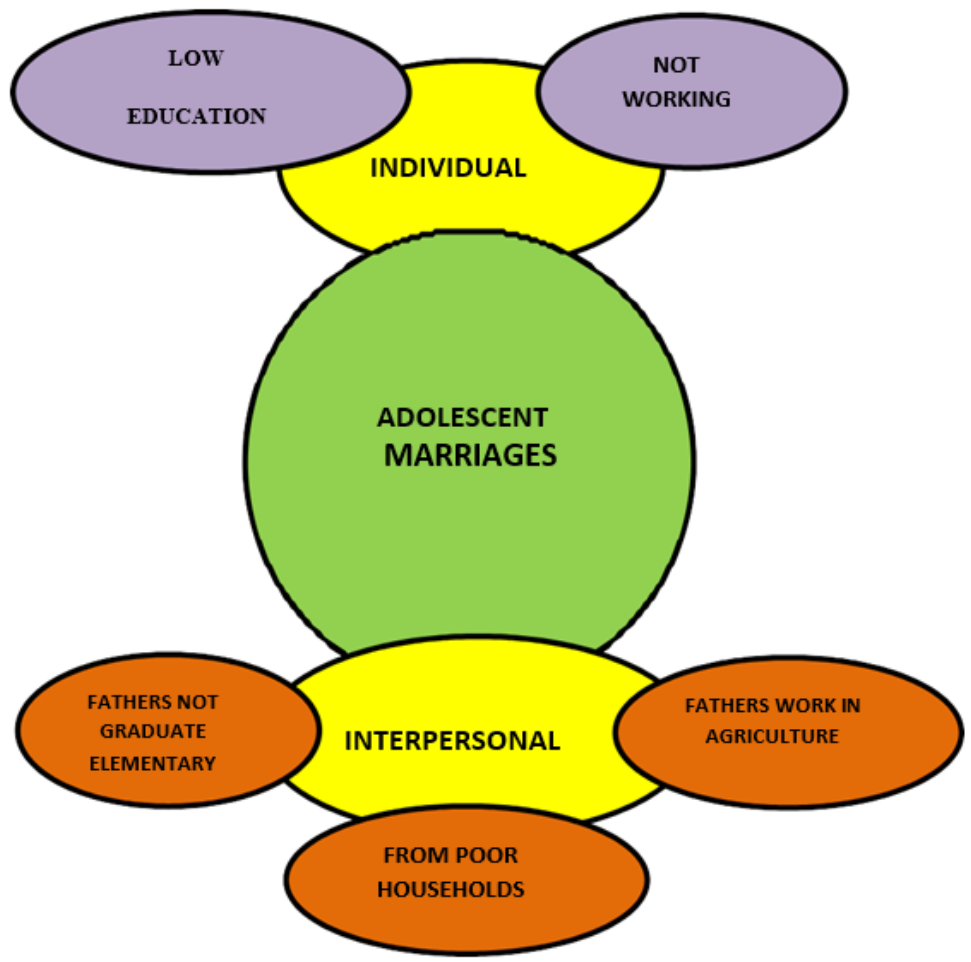

Figure 3. Model of Causing Factors of Adolescent Marriages

\section{CONCLUSION}

Based on the results of the analysis of 5 research variables, namely household economy, respondent education, respondent's work status, father's education and father's work status, those variables are the cause of the adolescent marriages. These five variables contributed to adolescent marriages by 35.7 percent (multivariate). The analysis shows that poverty experienced by young women contributes to adolescent marriages. Related to these conditions, there is a need to overcome poverty which is a dominant factor driving the adolescent marriages in order to strengthening social protection systems and improving parental education. This will impact on the work of parents, so that the household will have a prosper economic level. The quality of education service must be ensured and more employment opportunities to prevent adolescent marriages.

Further socialization of the marriage age maturity program needs to be promoted. Women should be married at the age of 21 and men will be married at least at 25 years old. In addition, it is necessary to intensify the socialization of Law No. 16/2019 concerning marriage 
which provides a minimum age limit of men and women allowed to marry is at least 19 years. Under the light that when the community understands the impact of women getting married at the ideal age, adolescent marriages will decrease and the biggest hope is that there will be no more cases of adolescent marriages in South Kalimantan in particular and in Indonesia in general.

\section{E. ACKNOWLEDGMENT}

The writer would like to express the special thanks for the Head of Study Program and colleagues in Geography Study Program, Faculty of Social Science and Political Science, Lambung Mangkurat University, and also the gratitude for Institute for Research and Community Service, Lambung Mangkurat University to the opportunity in the university's prime basic research.

\section{F. REFERENCES}

BPS\&UNICEF. (2016). Kemajuan yang Tertunda: Analisis Data Perkawinan Usia Anak di Indonesia. In Statistik Indonesia 2016 (p. 98). Badan Pusat Statistik.

BPS. (2020). Prevention of Child Marriage Acceleration that cannot wait (p. 71). PUSPAKA.

Chae, S., \& Ngo, T. D. (2017). The global state of evidence on interventions to prevent child marriage. GIRL Center Research Brief, https://www.popcouncil.org/uploads /pdfs/2017PGY_GIRLCenterResear chBrief_01.pdf

Handayani, E. (2014). Faktor-Faktor yang Berhubungan Dengan Pernikahan Usia Dini Pada Remaja Putri di Kecamatan Tambusai Utara Kabupaten Rokan Hulu. Jurnal Maternity and Neonatal, 1(2), 200206.

Hurlock, E. (1999). Development Psycology: An Approach Along The Live Circle (Translation). Erlangga.

Mcleroy, K. R., Bibeau, D., Steckler, A., \& Glanz, K. (1988). An Ecological Perspective on Health Promotion Programs. Health Education \& Behavior, 15(4), 351-377. https://doi.org/10.1177/1090198188 01500401

Muntamah, A. L., Latifiani, D., \& Arifin, R. (2019). Pernikahan Dini Di Indonesia: Faktor Dan Peran Pemerintah (Perspektif Penegakan Dan Perlindungan Hukum Bagi Anak). Widya Yuridika, 2(1), 1. https://doi.org/10.31328/wy.v2i1.82 3

Nasution, R. (2016). The Oppression of Women in the Anom Marriage Tradition: Subaltern of Women in Banjar Tribe in a Postcolonial Perspective. Yayasan Pustaka Obor Indonesia.

National Population and Family Planning Board (BKKBN), Statistics Indonesia (BPS), Ministry of Health (Kemenkes), and I. I. (2018). Indonesia Demographic Health Survey 2017. 623.

Undang-Undang Republik Indonesia Nomor 16 Tahun 2019 Tentang Perkawinan, (2019). http://www.koalisiperempuan.or.id/ wpcontent/uploads/2019/10/SalinanUU-Nomor-16-Tahun-2019-.pdf 
Pitoyo, A. J., Kiswanto, E., Karmila, E., Ardiansyah, J., Widyaningrum, N., \& Arbitraningrum, Y. T. (2011). Final Report Child Marriage in Indonesia.

Pohan, N. H. (2017). Faktor yang Berhubungan dengan Pernikahan Usia Dini terhadap Remaja Putri.. Jurnal Endurance, 2(3), 424-435. https://doi.org/10.22216/jen.v2i3.22
83

Santrock, J. (2003). The Development of Adolescence (Translation). Erlangga.

Wahyuni, S., Zirman, \& Natariasari, R. (2009). Pengaruh Motivasi Terhadap Minat Mahasiswa Akuntansi Untuk Mengikuti Pendidikan Profesi Akuntansi (PPAk). 1-15. 